\title{
The Role of Library and Information Science Education in the Development of Community Health Information Services for People Living with HIV/AIDS: Perspectives of Directors and Managers of Public Libraries
}

\author{
Bharat Mehra ${ }^{1}$, Adrienne Dessel ${ }^{2}$ \\ ${ }^{1}$ School of Information Sciences, University of Tennessee, Knoxville, USA; ${ }^{2}$ The Program on Intergroup Relations, University of \\ Michigan, Ann Arbor, USA. \\ Email: bmehra@utk.edu, adessel@umich.edu
}

Received July 5 ${ }^{\text {th }}$, 2011; revised August $10^{\text {th }}, 2011$; accepted August $18^{\text {th }}, 2011$.

\begin{abstract}
This article identifies the role of library and information science (LIS) education in the development of community health information services for people living with HIV/AIDS (PLWHA). Preliminary findings are presented from semistructured qualitative interviews that were conducted with eleven directors and managers of local branches in the Knox County Public Library (KCPL) System that is located in the East Tennessee region in the United States. Select feedback reported by research participants is summarized in the article about strategies in LIS education that can help local public librarians and others in their efforts to become more responsive information providers to PLWHA. Research findings help better understand the issues and concerns regarding the development of digital and non-digital health information services for PLWHA in local public library institutions.
\end{abstract}

Keywords: People Living with HIV/AIDS, PLWHA, Public Library Directors and Managers, Community Health Information Services

\section{Introduction}

The service-driven processes of information creation-organization-management-dissemination to meet the needs of various individuals and/or user-based communities (e.g., organizations, institutions, non-profit agencies, public and private enterprises, amongst others) form the core missions of the library and information science (LIS) professions [1,2]. Historically, in the United States their origins have been traced to the growth and development of different kinds of libraries (e.g., public, K-12 school, special, college and university libraries) [3] though their scope, boundaries, and nature of functionality has expanded with the advent of computers and the subsequent emergence and integration of information studies since the 1970 s $[4,5]$. In order to stay relevant in the $21^{\text {st }}$ century, LIS educators, practitioners, and researchers have recognized a need for innovative strategies in teaching, learning, and use of culturally sensitive information in traditionally discriminated areas to meet the needs of underserved populations on the margins of society [6-9]. Development of health information services for people living with HIV/AIDS (PLWHA) is one area that is marginalized in library practice, LIS education, information resource design, and community engagement efforts owing to continued cultural prejudice and stigma associated with the disease $[10,11]$. This is especially true for the American South that has the "greatest number of people estimated to be living with AIDS, AIDS deaths, and new AIDS diagnoses" [12]. Moreover, recent research shows that PLWHA in the southern states experience a lack of access and effective use of health information and preventive services $[13,14]$, as a result of special needs and environment/culture-specific factors such as minimal education, rural isolation, poverty and economic deprivation, racism and discrimination, and religious conserva- 
tism, amongst others [15,16].

In this marginalizing climate for PLWHA in the southern United States, LIS professionals can play a more proactive role (compared to current practice) in the development of community health information services for this disenfranchised population. Future health information service librarians can address various environmental, social, and cultural barriers to use of information by PLWHA, conditional upon their receiving adequate education and training about these and other issues regarding the development of health information services for PLWHA. Based on an awareness and learning about culturally appropriate knowledge in the digital age, health information service librarians can also address specific challenges in the advancement and use of electronic resources on health information services for PLWHA such as: aspects of physical and intellectual access, explosion of information on the Internet and the subsequent information clutter, information and computer literacy, and lack of authoritative and credible information resources, to name a few.

This article focuses on the role of LIS education in the development of community health information services for PLWHA based on preliminary findings from semistructured interviews with eleven directors and managers of local branches in the Knox County Public Library (KCPL) System located in the East Tennessee region. Select feedback reported by research participants is summarized in the article about strategies in LIS education that can help local public librarians and others in their efforts to become more responsive information providers to PLWHA. Research findings help better understand the issues and concerns regarding the development of digital and non-digital health information services for PLWHA in local public library institutions. Future publications will provide a more detailed and complete analysis of health information services for PLWHA in other regional and national libraries.

\section{HIV/AIDS in LIS}

Historically, since the time when AIDS was first recognized by the U.S. Centers for Disease Control and Prevention in 1981 and its cause, HIV, identified in the early 1980s [17,18], the disease has drawn some attention in LIS research and service provision. For example, Jeffrey T. Huber and Mary L. Gillapsy recognized the social circumscriptions surrounding the HIV/AIDS body of knowledge in its pathological dimensions and called for a controlled vocabulary that would "facilitate knowledge organization and access relative to HIV/AIDS" to "reflect the complexities of this socially constructed reality" [19]. HIV/AIDS representation, according to
Hanne Albrechtsen and Elin K. Jacob's non-traditional classification scheme [20] as a transitional element or "boundary object" provided a "mediating vocabulary" to facilitate communication between the different communities involved with the HIV/AIDS epidemic and integrated interdisciplinary perspectives and research on the HIV/AIDS lived experience to embody the "social worlds constituting an information system and the collective conditions for knowledge production" [21]. Challenges for LIS professionals in HIV/AIDS information service delivery have included: 1) Merger of the traditional roles of creators, seekers, and providers of HIV/AIDS-related information leading to its production and consumption at multiple intertwined levels (i.e., individual, organizational, institutional, community, local, regional, national, and international) [22]; 2) Interweaving of the HIV/AIDS vernacular language and vocabulary with the technical, scientific, and biomedical terminology to develop its very-specific and interdisciplinary lexicon [23,24]; 3) Exponential growth in the volume of HIV/AIDS information and research with the rise in the number of documented HIV/AIDS cases [25,26] in different parts of the world such as in Asia and Africa [27,28].

Various conferences, events, and reports on HIV/ AIDS, sponsored by the National Institutes of Health and the National Library of Medicine, amongst others, have been developed to generate dialogue, discussion, and recommendations for effective provision of HIV/AIDS information services to people affected by the disease $[29,30]$. Subjects and topics have included general HIV/ AIDS information as well as targeted health information services for special populations including: teens and adolescents [31], racial and ethnic minorities [32,33], women of color [34], gay and bisexual men [35], and other high-risk populations. Additional HIV/AIDS information and topics in LIS research and service provision include access to HIV/AIDS information sources/resources [36,37], HIV/AIDS information needs of the underserved facing health information service inequities owing to intersecting variables (e.g., race/ethnicity and sexual orientation) [38], HIV/AIDS representation in fiction literature [39], international partnerships in HIV/AIDS research [40], to name a few. What has been conspicuous by its absence in the past body of LIS work on HIV/ AIDS is a direct involvement and explicit documentation of LIS education (i.e., educators and students) in incorporating HIV/AIDS issues in its teaching agenda and classroom activities. This article is an exploratory attempt to fill this missing gap from the point of view of one group of stakeholders associated with the provision of HIV/AIDS health information and services, namely, the directors and managers of local branches in the 
KCPL System located in the East Tennessee region.

\section{The Research Context}

Historically, since the nineteenth century public libraries in the United States have been involved in reaching out to meet the needs of distressed communities such as immigrants, racial and ethnic minorities, low-income families, women of color, rural residents, inner-city kids, people with chronic and life-threatening diseases, amongst others $[41,42]$. Hence, the focus of this research to study directors and managers of public libraries is apt since it highlights the perspectives of a group that represents an institution of long-standing history of engagement with disenfranchised populations [43,44]. Public libraries in the United States have different policies and practices regarding requirements of a master's degree for individuals in the public library leadership positions in the different states that has led to their identification as directors or managers and the importance of this has been much debated and contested without developing comprehensive and uniform practice [45-47]. Tennessee does not have a requirement of a master's degree for individuals in its public library leadership positions leading to the selection of both directors and managers as interviewees in this research.

The KCPL System is embedded in Knoxville, Tennessee, and adjoining areas in the eastern part of the state. Knoxville has a population of nearly 183,000 in the city, with slightly over 411,000 in the county area. It is the third largest city in the state and is home to the University of Tennessee (UT) main campus, the Tennessee Valley Authority, and the nearby Oak Ridge National Laboratory and Smoky Mountain National Park, both within a 30 mile radius. Knoxville's population is nearly $80 \%$ white, over $16 \%$ African American, and the remaining $4 \%$ consists of Native American, Asian, and those of Hispanic or Latino background. The median household income is over $\$ 27,000$, and the per capita residents of Knoxville average \$18,171 income per year, with over $20 \%$ of individuals living below poverty level. Men report higher incomes of just over \$29,000 followed by women at $\$ 22,500$ [48].

The KCPL System [49] has a long history from 1885 of providing library resources to the people of Knox County. Today, the collections are delivered via over 20 facilities and contain more than a million volumes, circulating 2,374,152 items per year, to a population of plus 392,995 residents [50]. These facilities are dispersed across the county and share electronic and references services as well as some administrative and managerial responsibilities. From innovative programming and efficient reference and user instruction to the use of latest technology to meet the needs of various audiences, the KCPL System provides unique community-based services (e.g., Local History and Genealogy, Teen Central, Sights \& Sounds, etc.) that reflect its special position and role in the East Tennessee region.

The Tennessee Department of Health [51] reported that the number of people still alive who have an HIV diagnosis increased dramatically from 2001 to 20059166 to 11,867 , as did the number living with AIDS, from 5021 to 6133. During 2004, Tennessee had an estimated 1108 newly diagnosed cases of HIV/AIDS, while the number of new HIV/AIDS cases in Knox County has ranged from 55 to 63 each year from 2001-2005 [52]. Based on data provided by the Hope Center [53] in Knoxville's Fort Sanders Regional Medical Center, through December 2006, Tennessee had an estimated 20,685 cases of HIV, of which an estimated 2700 were children/young adults under the age of 25 years. In the South between 2001-2005 AIDS cases increased by 19\% and deaths decreased in all regions but the South [54]. Women accounted for $23 \%$ of the HIV/AIDS cases in Tennessee during the same period; girls between the ages 13 - 19 years represent $8 \%$ of new HIV infections in the South, which is four times the rate found elsewhere in the United States. New HIV/AIDS diagnoses among Black, non-Hispanics continue to be disproportionately high in the state with $59 \%$ of newly diagnosed HIV/AIDS cases in 2004 identified from the Black, non-Hispanic population [55].

According to the Tennessee HIV Data [56], there were 691 PLWHA in the Knox consortia region as compared to the cumulative PLWHA data of 12,329 for the state of Tennessee through March 31, 2004; there were 532 persons diagnosed with AIDS in the Knox consortia region while the cumulative data statewide was 9631 through the same time. A seven-part series examining the HIV/ AIDS epidemic in East Tennessee that was published in the Knoxville News Sentinel during August 2005 entitled "Living Positive: HIV/AIDS in East Tennessee" addressed issues of health information services for PLWHA in the light of increasing numbers of HIV/AIDS cases in the region. Salient highlights from the series included: 1) Role of religious conservatism and prejudice in creating negative stigma towards PLWHA who encounter daily discrimination, bureaucracy, and insensitivity in Knoxville's health-care professions; 2) Alarming spread of the HIV/AIDS virus amongst ethnic minorities (of both genders) and the urgency for developing appropriate health information services to respond to their changing needs [57]; 3) Rural populations have not remained unaffected. For example, the Centers for Disease Control and Prevention [58] report that two-thirds of those in 
rural areas in the South are infected locally by the HIV/ AIDS virus, as compared to early days of the epidemic when most people got the virus from someone outside their own community; 4) Creating education and awareness is very important, especially among young Americans, to stop the spread of HIV/AIDS since this demographic population is "at persistent risk" of HIV infection; 5) Important contributors to increasing transmission rates of HIV/AIDS include higher rates of alcohol and drug abuse, inadequate and limited access to health-care resources, lack of health insurance, and higher rates of other sexually transmitted diseases (which increase risk of HIV infection); 6) Low-income and economic deprivation, in addition to changes in coverage terms provided by TennCare, the state health insurance system, have resulted in swelling numbers of HIV/AIDS patients losing their benefits and in severe trouble once the new policies began in 2006. A recent cover story entitled "HIV: On the Homefront" [59] in the Metro Pulse, Knoxville's local newsmagazine, highlights that much has not changed over the past three years in terms of Knoxville's "judging and shunning" and discrimination for PLWHA, in spite of changes in improved life expectancy, institutional help, and demographics.

\section{Methodology}

The methods and procedures adopted in this research were initially developed in a related project in its first phase that explored HIV/AIDS information services available within the local community of Knoxville from the perspectives of nine academic library and information professionals about the awareness and use of these services by PLWHA [60]. The current article reports findings from the project's second phase of documenting perspectives of eleven public library branch directors and managers in the KCPL System about existing HIV/AIDS information services, users of these services, barriers and challenges to effective use, and the role of LIS educators in the context of developing ideal information support services for PLWHA. Research participants are representative directors and managers in the KCPL System and were selected based on size and location of their library branch, community service profile of their library branch, availability and convenience, and their willingness to participate in the study.

The semi-structured interview method adopted in this research provided a focused and in-depth dataset from a limited set of select participants located in one city in the conservative "buckle of the bible-belt" about issues and concerns related to the availability (or lack of availability) of HIV/AIDS information services in local public libraries. Research interviews lasted for 1.5 - 2.0 hours and were conducted at the participant's branch library. Consent forms were distributed to research participants prior to the interviews and the interviews were audio-taped to maintain accurate documentation of participant's feedback. The two researchers also took notes during the interviews. Only the researchers were involved in the transcription of data collected during the interviews to maintain strict confidentiality of the research participants. Grounded theory principles $[61,62]$ were used to identify themes via content analysis of the qualitative data gathered during the interviews. As a token of appreciation for allowing their directors and managers to participate in the study, the KCPL System was provided a \$200 gift to purchase information materials on HIV/AIDS for their collection. Following the interviews, ongoing conversations about the information support services offered at the KCPL System was maintained with select participants over the period since.

\section{Research Findings}

The study yields significant findings about the role of LIS educators and students in the development of a community health information system for PLWHA in terms of: what would be useful, who can help this population, what resources are available, how can public library information providers and LIS educators collaborate to bring about change and become more effective in reaching out to PLWHA, and what role can information technology play in bringing about effective change in public library environments. The results from the interviews are summarized and presented below under each of the topical questions that were asked during the interview. The semi-structured questions were developed by the researchers in advance of the interviews to guide the process of collecting feedback from the research participants. The questions were designed to identify information services in the area that provided assistance to PLWHA. They were designed to elicit particular feedback about the information services in the community. Each question yielded much more data than presented in this article; here the focus of analysis is on participant feedback about the role of LIS education in the development of community health information services for PLWHA.

\subsection{Question One: Identify Your Public Library and Work Responsibilities}

All the research participants were directors or managers of local branches in the KCPL System. Some research participants had master's degrees in library science (or information science) while others did not. In order to maintain participant anonymity the article does not pro- 
vide additional feedback about the specific number of research participants with/without master's degrees since the participant pool was small and can be easily identifiable. An important note, however, made by at least three research participants was the need for a potential collaboration between the UT's LIS program (i.e., School of Information Sciences) and the KCPL System to support degree attainment by managers who were not master's graduates. It was believed that such an effort would allow for professional development of individual managers who did not have a master's degree, and also improve service provision (including health information services for PLWHA) in their branch libraries.

Research participants reported on their management and supervision role in their branch libraries. Their employees ranged from 3 - 21 full time staff members, including 11 reference librarians in the main library. Other library staff included part time workers, paraprofessionals, and volunteers. Three research participants referred to the high quality and value provided by LIS students when they joined the KCPL System's workforce and called for more student involvement in developing health information services in the KCPL's branch libraries via independent study, practicum, and course work. Research participants also described their service roles in systemwide library committees (e.g., ordering, purchasing, and selection committee; efficiency committee; planning and coordinating committee for special programs; children's development committee, etc.). None mentioned evidence to suggest any system-wide committee participation to develop health information services for PLWHA.

\subsection{Question Two: What Are the Existing HIV/AIDS Information Services for PLWHA in the KCPL System and in the Greater Knoxville Community?}

There was a consensus among research participants that the KCPL System provided few and outdated materials on HIV/AIDS. For example, one research participant stated that the latest work on HIV/AIDS in the collection dated from 2003. Two branch directors or managers stated that items in their collection varied for adults and children, in both fiction and non-fiction, though all research participants called for more authoritative materials on HIV/ AIDS. Four research participants suggested sharing of resources/services with the University's library network to address this limitation in their collection. Three research participants stated that they sometimes called the Preston Medical Library at UT's Medical Center for health-related reference questions.

Research participants' knowledge and awareness of available health information services varied based on their subject expertise, searching skill level, work load and responsibilities, enthusiasm for their job and profession, significance of the topic to their patrons in the locality, interest level, and attainment of master's degree. For example, one research participant identified 300 items while another stated that she had 26 titles available in the KCPL System. A third research participant said that there were 12 items in her collection though she could make avail of the collections provided at other branch libraries when there was a patron request for a particular title.

According to one participant, such variation in knowledge and perception might illuminate two internal issues at the KCPL (issues that exist in other multi-service point libraries as well) in terms of data collection: 1) Possibly, the branch managers providing such varied feedback are answering the question about their branch only and not about the system-wide resources that are available to them. 2) There might also be a tendency to think in terms of books, and to forget about journal articles and online resources. Two research participants suggested a need for them to participate in training workshops on available HIV/AIDS information services and possible involvement of LIS faculty in implementing such an activity.

Research participants stated that items in their collection varied from print materials (e.g., books, magazines) to electronic sources and authoritative websites on the subject. Seven research participants suggested that it would be extremely helpful for them if interested LIS students developed a "best list" of websites and print resources on HIV/AIDS as part of their course assignments. Research participants relied on the reference databases available via the Tennessee Electronic Library (TEL) and the health and wellness resource section to find general or encyclopedia-like information on HIV/AIDS, though several pointed to a lack of focused and technical or medical sources in the collection.

\subsection{Question Three: Who Uses These Services?}

Research participants mentioned that they did not monitor their patrons' behavior in the library so it was difficult for them to provide a specific response beyond a speculation. Yet, they believed that there were a significant number of audiences who used health information services on HIV/AIDS. These included: PLWHA, patients' family members, people in the community interested in the social/medical dimensions of the disease, students and teens, and others.

\subsection{Question Four: How Often Do You Encounter People Using Services Related to HIV/AIDS?}

Most of the research participants reported that they had 
Services for People Living with HIV/AIDS: Perspectives of Directors and Managers of Public Libraries

rarely encountered a patron who asked questions about HIV/AIDS. One research participant, however, explained that though she never had an adult ask HIV/AIDS-related questions, she did occasionally (i.e., five or six times a year) have high school students inquire about HIV/AIDS for class reports. In comparison, eight research participants pointed out that a number of library patrons asked for books or magazines on other health-related concerns (e.g., bipolar, women's health, reproductive health, autism, cancer, diabetes, blood pressure, and medication issues), just not HIV/AIDS.

\subsection{Question Five: Why Are Patrons Not Asking about HIV/AIDS Information Services in the KCPL System?}

Research participants attributed the main reason for a lack of patron questions on HIV/AIDS to the pervading stigma and prejudice associated with the disease. Other reasons included: reluctance to address the topic in public, conservative nature of the embedded community, patron's fear to disclose that they were a HIV/AIDS patient, patron's reliance on their own information seeking, availability of information on the Internet, patrons' high perception of their searching skills, provision of information from health care providers, and complacency owing to improved health treatments.

\subsection{Question Six: What Are the Barriers and Challenges That Public Library Information Professionals Face in Providing These Services for PLWHA?}

There were many barriers and challenges that research participants identified regarding the provision of HIV/ AIDS information services in their public library environments. Top amongst them were the cultural and political climate of embarrassment and stigma regarding information on HIV/AIDS and a "reluctance to ask in a public environment.” Research participants encountered this reluctance in patron's behavior to talk about HIV/ AIDS and discuss what information they needed. Research participants also experienced the reluctance of the administration and management in their inability to recognize HIV/AIDS as an important topic for adequate budget allocation and resource allotment. An important point to note here is that though it is true that some branches are not receiving as many new books because their use statistics do not warrant it, however, their library catalog accesses all the material in the KCPL System, and items can be borrowed from another point of service. Other identified barriers included: lack of awareness and access to accurate and authoritative information, consistent and current information about HIV/AIDS, less available materials published on HIV/AIDS and lack of financial resources to develop adequate collections, complaints from the public about HIV/AIDS information on the bookshelves, finding age appropriate HIV/AIDS materials for children, and poor public perception and negative stereotypes of librarians (e.g., not willing to help, no relevant health information in the library, etc.). Several research participants identified multiple times the role of LIS education and academic libraries to develop and share collections, services, resources, and facilities to help public libraries address the identified barriers and challenges they faced in providing HIV/AIDS information to their local constituencies.

\subsection{Question Seven: What Would Be an Ideal HIV/AIDS Information Service (Based on Challenges Identified by the Research Participants)?}

Research participants were asked to identify what an ideal HIV/AIDS information service would look like in a public library environment, given the limitations they had just identified. They answered this question in relation to what would be useful for the library and information professionals to know, who could help them, and what resources are (or should be) available. The result was a "laundry list" presented in Table 1.

\section{Discussion}

The public librarians who participated in this research identified the need for building inter-professional and intra-professional ties, as well as other community collaborations, to address the challenges they faced in providing effective health information services for PLWHA in their local communities. Inter-professional communication and interactions with local health care service providers, medical practitioners, and general and specialized physicians, were considered significant for developing:

- Lists of high quality, up-to-date materials to purchase for library collections;

- A consolidated "umbrella website" that brings together recommended resources;

- A memorandum distributed from the county health services department with an updated list of authoritative sources on HIV/AIDS;

- Ongoing feedback from health care professionals about the needs, wants, and information-related behaviors of their HIV/AIDS clients;

- Compilations of community health information services for PLWHA for referral purposes based on different agency's varied policies, costs, facilities, expectations, criteria of patient selection, etc.;

- Information on current HIV/AIDS research and possibilities in the future. 
Table 1. Components of an “ideal” HIV/AIDS information service in public libraries.

\begin{tabular}{cc}
\hline $\begin{array}{c}\text { Brochure on general health information with a special section on } \\
\text { HIV/AIDS }\end{array}$ & Referral to local hospitals, clinics, and support groups \\
\hline Reference source for people to self-examine & Workshops and educational seminars \\
"Best list” of websites & K-12 schools and colleges to promote education \\
Internet-based resources/services & LIS educators, students, and academic libraries for sharing \\
information resources & Collaborations with churches to dispel ignorance and hate \\
Database containing current and updated materials & Commity partnerships with non-profits working on HIV/AIDS \\
issues
\end{tabular}

Research participants also called for intra-professional connections with different LIS educators, students, medical and academic librarians, and others, in order to collaborate in areas such as resource sharing, access delivery mechanisms, collection development, conducting needs assessment of various audiences, and management of personnel distribution to achieve mutually identified goals towards improved health information services for PLWHA. Developing intra-professional ties were also considered important to facilitate the inter-professional collaborations identified above. LIS educators and students were identified as possible facilitators to develop interactions between public librarians, medical professionals, and others from various health-related professions. Additionally, research participants identified different community constituencies who could potentially help them locally improve their services for PLWHA such as: people from HIV/AIDS support groups, social workers and community activists working on HIV/AIDS issues, community service providers in hospitals, religious leaders and pastors, schools and teachers to educate the children on HIV/AIDS, funders for development of HIV/ AIDS information resources, book reviewers and publishers selling HIV/AIDS materials, public in helping to educate consumers, and others who could offer relevant and free (or low-cost) information materials and services on HIV/AIDS.

Moreover, research participants called for tapping into existing resources available to address the identified challenges in providing health information services for PLWHA. Existing efforts included: distribution of HIV/ AIDS pamphlets from the UT's medical and health departments, role of the county health department as a provider of information services on HIV/AIDS, reference department in the KCPL's downtown branch, local bookstores, authoritative websites on HIV/AIDS infor- mation, researchers doing studies on HIV/AIDS, support groups, and select community agencies providing HIV/ AIDS materials.

\section{Conclusions}

The focus of this research was on the perspectives of local library branch directors/managers in the KCPL System about available health information services for PLWHA and the role of LIS education in the development of culturally appropriate community health information services for the disenfranchised population. Feedback provided by research participants identifies potential partnerships between local public libraries and LIS educators and students as a significant step in developing inter-professional and intra-professional ties, as well as nurturing community collaborations, to achieve the ideal service and become more effective in reaching out to PLWHA. Strengthening of professional ties with LIS education were believed to improve existing HIV/ AIDS information services in public libraries in areas of: current and updated collection development, information dissemination and marketing in local communities (e.g., development and distribution of flyers on HIV/AIDS), addressing negative public perception about libraries and the LIS professions, developing referrals to community information services, providing multiple modes and formats of information delivery, writing collaborative grant projects to provide financial support in developing HIV/ AIDS information services, and implementing HIV/ AIDS workshops for different populations (e.g., teens, seniors, and ethnic minorities). Such information-related work can be undertaken by LIS educators and students in required and elective course assignments, independent studies, practica, participation in community activities, involvement in externally funded projects, etc. LIS education and information technology were believed to play 
an important role in bringing about positive changes in public libraries for PLWHA in terms of: developing a consolidated information resource (e.g., HIV/AIDS health and wellness database), organizing more current and updated online information on the library websites, helping in computer training to empower PLWHA to find their own relevant information, and, advertising and marketing of the KCPL's health information and services for PLWHA.

Next research steps will involve sharing of a more detailed framework to develop health information services for PLWHA in Knoxville's public libraries. Feedback collected from a larger pool of public librarians in Tennessee will also be reported. Follow-up efforts will examine the provision of health information services for PLWHA from the perspective of other stakeholders including local PLWHA, health care service providers, community leaders and activists, and faith-based organizations, amongst others. Gathering feedback from different constituencies involved in the provision of health information services for PLWHA will insure acknowledgement of diverse realities and experiences in order to make real progress and bring progressive social changes that are meaningful to all concerned.

\section{Acknowledgements}

The authors are thankful to the library directors/managers who participated in this research for sharing their experiences and perspectives about existing health information services for PLWHA in their branch libraries. We also thank the Deans Summer Grant from the UT's College of Communication and Information for financial support while conducting this research. The authors appreciate the feedback received from the online participants and on-site audience for the juried paper session that was presented at the Association for Library and Information Science Education 2009 Annual Conference.

\section{REFERENCES}

[1] J. H. Shera and D. B. Cleveland, "History and Foundations of Information Science,” In: M. E. Williams, Ed., Annual Review of Information Science and Technology, Vol. 12, Knowledge Industry Publications Inc., White Plains, New York, 1979, pp. 249-275.

[2] P. Vakkari, "From Library Science to Information Studies,” In: R. Verwer, J. Nijboer and R. Bruyns, Eds., The Future of Librarianship: Proceeding of the 2nd International Budapest Symposium, Hogeschool van Amsterdam, Faculteit, Economie en Informatie, Amsterdam, 1994.

[3] M. H. Harris, "History of Libraries in the Western World," 4th Edition, Scarecrow Press, Lanham, 1995.

[4] M. Buckland and Z. Liu, "History of Information Science,” In: T. B. Hahn and M. Buckland, Eds., Historical
Studies in Information Science, Information Today Inc., American Society for Information Science, Medford, 1998, pp. 272-295.

[5] W. B. Rayward, "International Federation for Information and Documentation,” In: W. A. Wiegand and D. G. David Jr., Eds., The Encyclopedia of Library History, Garland Publishing, Inc., New York, 1994, pp. 290-294.

[6] I. Abdullahi, "Diversity and Intercultural Issues in Library and Information Science (LIS) Education, New Library World, Vol. 108, No. 9-10, 2007, pp. 453-459. doi:10.1108/03074800710823980

[7] G. Benoit, "Critical Theory and the Legitimation of LIS," Information Research, Vol. 12, No. 4, 2007. http://InformationR.net/ir/12-4/colis30.html

[8] B. Mehra, K. Black and S. Lee, "Perspectives of East Tennessee's Rural Public Librarians about the Need for Professional Library Education: An Exploratory Study," Journal of Education for Library and Information Science, Vol. 51, No. 3, 2010, pp. 142-157.

[9] B. Mehra, H. A. Olson and S. Ahmad, "Integrating Diversity across the LIS Curriculum: An Exploratory Study of Instructors' Perceptions and Practices Online,” International Federation of Library Associations and Institutions (IFLA) Journal, Vol. 37, No. 1, 2011, pp. 39-51.

[10] R. Parker, P. Aggleton, K. Attawell, J. Pulerwitz and L. Brown, "HIV/AIDS-Related Stigma and Discrimination: A Conceptual Framework and an Agenda for Action," 2002. http://www.dec.org/pdf_docs/PNACQ832.pdf

[11] UNAIDS, "Reducing HIV Stigma and Discrimination: A Critical Part of National AIDS Programmes, A Resource for National Stakeholders in the HIV Response,” Joint United Nations Programme on HIV/AIDS, Geneva, 2007. http://data.unaids.org/pub/Report/2008/jc1420_stigma_di scr_en.pdf

[12] Kaiser Family Foundation, "HIV/AIDS Policy Fact Sheet: The HIV/AIDS Epidemic in the United States, Impact across the Country section, Para. 3,” Washington DC, July 2007.

http://www.kff.org/hivaids/upload/3029-071.pdf

[13] L. Espinoza, K. L. Dominguez, R. A. Romaguera, X. Hu, L. A. Valleroy and H. I. Hall, "HIV/AIDS among Hispanics-United States, 2001-2005,” Morbidity and Mortality Weekly Report (Newsletter), Thompson Gale, New York, 12 October 2007.

[14] S. Hunter, “AIDS in America,” Palgrave Macmillan, New York, 2006.

[15] R. E. Beckley and J. R. Koch, “The Continuing Challenge of AIDS: Clergy Responses to Patients, Friends, and Families,” Auburn House, Boston, 2002.

[16] D. D. Wessner, "The AIDS Pandemic: HIV/AIDS in the Southeastern United States," 2006. http://the-aids-pandemic.blogspot.com/2006/11/hivaids-in -southeastern-us.html

[17] R. C. Gallo, "A Reflection on HIV/AIDS Research after 25 Year,” Retrovirology, Vol. 3, 2006, p. 72. doi:10.1186/1742-4690-3-72 
[18] M. S. Gottlieb, "Pneumocystis Pneumonia—Los Angeles 1981," American Journal of Public Health, Vol. 96, No. 6, 2006, pp. 980-983.

[19] J. T. Huber and M. L. Gillapsy, "Social Constructs and Disease: Implications for a Controlled Vocabulary for HIV/AIDS,” Library Trends, Vol. 47, No. 2, 1998, p.190.

[20] H. Albrechtsen and E. K. Jacob, "The Dynamics of Classification Systems as Boundary Objects for Cooperation in the Electronic Library,” In: G. C. Bowker and S. L. Star," Eds., How Classifications Work: Problems and Challenges in an Electronic Age (A special issue), Library Trends, Vol. 47, No. 2, 1998, pp. 203-312.

[21] S. L. Star, "The Structure of Ill-Structured Solutions: Boundary Objects and Heterogeneous Distributed Problem Solving, In: L. Gasser and M. N. Huhns, Eds., Distributed Artificial Intelligence, Pitman, London, 1989, pp. 37-54.

[22] D. S. Ginn, “The AIDS Information Crisis: Confluence of Roles of Information Creator, Seeker, and Provider,” Bulletin of the Medical Library Association, Vol. 75, No. 4, 1987, pp. 333-341.

[23] J. T. Huber, "Dictionary of AIDS-Related Terminology," Neal-Schuman, New York, 1993.

[24] J. T. Huber and M. L. Gillaspy, "HIV/AIDS and HIV/ AIDS-Related Terminology: A Means of Organizing the Body of Knowledge,” Haworth, New York, 1997.

[25] T. Stanton, "HIV/AIDS and Information,” Kindle Edition, Taylor and Francis, London, 2007.

[26] B. Wexler, "AIDS/HIV (Information Plus Reference Series),” Gale Cengage, Florence, 2008.

[27] L. Dube, "Insights into the Diffusion of HIV/AIDS Information in Higher Education Institutions in South Africa," The International Information and Library Review, Vol. 37, No. 4, 2005, pp. 315-327. doi:10.1016/j.iilr.2005.10.001

[28] S. K. Patra and P. Chand, "HIV/AIDS Research in India: A Bibliometric Study," Library and Information Science Research, Vol. 29, No. 1, 2007, pp. 124-134. doi:10.1016/j.lisr.2006.08.010

[29] U. S. Department of Health and Human Services, "Information Services for HIV/AIDS: Recommendations to the NIH: Report of a Conference Co-sponsored by the National Library of Medicine and the NIH Office of AIDS Research, June 28-30, 1993,” U. S. Department of Health and Human Services, Public Health Service, National Institutes of Health, Bethesda, 1994.

[30] U. S. Department of Health and Human Services, "Guide to NIH HIV/AIDS Information Services, with Selected Public Health Service Activities,” U. S. Department of Health and Human Services, Public Health Service, National Institutes of Health, Bethesda, 1995.

[31] Centers for Disease Control and Prevention, "HIV/AIDS Surveillance in Adolescents and Young Adults," Through 2006, 2003.

http://www.cdc.gov/hiv/graphics/adolesnt.htm
[32] B. R. Flay, S. Gramlich, E. Segawa, J. L. Burns and M. Y. Holliday, "Effects of Two Prevention Programs on High Risk Behaviors Among African-American Youth,” Archives of Pediatrics \& Adolescent Medicine, Vol. 158, No. 4, 2004, pp. 337-384. doi:10.1001/archpedi.158.4.377

[33] F. Sabogal and J. A. Catania, "HIV Risk Factors, Condom Use, and HIV Antibody Testing Among Heterosexual Hispanic/Latinos: The National AIDS Behavioral Surveys (NABS)," Hispanic/Latino Journal of Behavioral Sciences, Vol. 18, 1996, pp. 367-391.

[34] M. Suarez-Al-Adam, M. Raffaelli and A. O'Leary. "Influence of Abuse and Partner Hypermasculinity on the Sexual Behavior of Latinas," AIDS Education and Prevention, Vol. 12, 2000, pp. 263-274.

[35] P. A. Vanable, D. G. Ostrow, D. J. McKirnan, K. J. Taywaditep and B. A. Hope, "Impact of Combination Therapies on HIV Risk Perceptions and Sexual Risk Among HIV-Positive and HIV-Negative Gay and Bisexual Men," Health Psychology, Vol. 19, No. 2, 2000, pp. 134-145. doi:10.1037/0278-6133.19.2.134

[36] National Institutes of Health and National Library of Medicine, "HIV/AIDS Information Resources," NIH Publication, Number 96-4134, National Institutes of Health, Bethesda, 1996.

[37] M. Novellino and S. Ferreira, "Information Sources for a Diverse Audience: The Case of HIV/AIDS,” In: H. A. Olson, Ed., Information Sources in Women's Studies and Feminism, K. G. Saur, Munich, 2002, pp. 117-127. doi:10.1080/09540120600568731

[38] S. D. Rhodes, L. J. Yee and K. C. Hergenrather, "A Community-Based Rapid Assessment of HIV Behavioural Risk Disparities within a Large Sample of Gay Men in Southeastern USA: A Comparison of African American, Latino and White Men,” AIDS Care, Vol. 18, 2006, pp. 1018-1024.

[39] M. Gross, A. Goldsmith and D. Carruth, "What do Young Adult Novels Say about HIV/AIDS? A Second Look," The Library Quarterly, Vol. 78, No. 4, 2008, pp. 397-418. doi:10.1086/591181

[40] O. B. Onyancha and D. N. Ocholla, "Country-Wise Collaborations in HIV/AIDS Research in Kenya and South Africa, 1980-2005," Libri: International Journal of Libraries and Information Services, Vol. 57, No. 4, 2007, pp. 239-254.

[41] K. de la Pena McCook, "Introduction to Public Librarianship,” 2nd Edition, Neal-Schuman Publishers Inc., New York, 2011.

[42] B. Mehra and R. Srinivasan, "The Library-Community Convergence Framework for Community Action: Libraries as Catalysts of Social Change," Libri: International Journal of Libraries and Information Services, Vol. 57, No. 3, 2007, pp. 123-139.

[43] L. A. Martin, "Enrichment: A History of the Public Library in the United States in the Twentieth Century, Scarecrow Press, Lanham, 1998.

[44] B. Mehra, K. Rioux and K. S. Albright, "Social Justice in 
Services for People Living with HIV/AIDS: Perspectives of Directors and Managers of Public Libraries

Library and Information Science,” In: M. J. Bates and M. N. Maack, Eds., Encyclopedia of Library and Information Sciences, Taylor and Francis Group, New York, 2009.

[45] M. Biggs, "Sources of Tension and Conflict between Librarians and Faculty," Journal of Higher Education, Vol. 52, No. 2, 1981, pp. 182-201. doi:10.2307/1981090

[46] H. S. White and M. Paris, "Employer Preferences and the Library Education Curriculum,” The Library Quarterly, Vol. 55, No. 1, 1985, pp. 1-33. doi:10.1086/601557

[47] W. Wiegand, "Tunnel Vision and Blind Spots: What the Past Tells Us about the Present; Reflections on the Twentieth-Century History of American Librarianship," The Library Quarterly, Vol. 69, No. 1, 1999, pp. 1-32. doi:10.1086/603022

[48] U. S. Census Bureau, "State and County QuickFacts. Data Derived from Population Estimates, Census of Population and Housing, Small Area Income and Poverty Estimates, State and County Housing Unit Estimates, County Business Patterns, Nonemployer Statistics, Economic Census, Survey of Business Owners, Building Permits, Consolidated Federal Funds Report,” 2000.

http:/quickfacts.census.gov/qfd/states/47000.html

[49] Knox Country Public Library, "Knox County Public Library: It’s the Smart Place To Be!" http://knoxrooms.sirsi.net/rooms/portal/media-type/html/l anguage/en/country/US/user/anon/page/Sirsi_HOME

[50] Lib-Web-Cats, "A Directory of Libraries throughout the World: Knox County Public Library System,” 2007. http://www.librarytechnology.org/lwc-displaylibrary.pl?R $\mathrm{C}=749$

[51] Tennessee Department of Health, "HIV Maps,” 2005 http://health.state.tn.us/STD/maps.html

[52] Tennessee Department of Health, “2005 Tennessee Integrated Epidemiologic Profile for HIV/AIDS Prevention and Care Planning," Department of Health HIV/AIDS/ STD Program (Surveillance and Data Management Section), Nashville, 2005. http://www.coetenn.com/PDFfiles/2005MASTEREpiProf ile1012.pdf
[53] Hope Center, “Hope is the Belief in Possibilities,” 2008. http://hopecenterknox.org/resources.html

[54] Centers for Disease Control and Prevention, "TwentyFive Years of HIV/AIDS-United States, 1981-2006," Morbidity and Mortality Weekly Rrport, Vol. 55, No. 21, 2006, pp. 585-589.

[55] Centers for Disease Control and Prevention, “2006 Disease Profile: National Center for HIV/AIDS, Viral Hepatitis, STD, and TB Prevention,” Centers for Disease Control and Prevention, Atlanta, 2008. http://www.cdc.gov/nchhstp/Publications/docs/2006_Dise ase_Profile_508_FINAL.pdf

[56] State of Tennessee Department of Health, "Tennessee HIV Data: 2004 Cumulative Data Maps for Tennessee through 12/31/2004,” 2002, Last Edit: 2008 http://www.coetenn.com/HIVdata/HIVdataCumulative.htm

[57] J. Hunter, “'Not a Big-City Disease Anymore', Living Positive: HIV/AIDS in East Tennessee,” Knoxville News Sentinel, August 2005.

[58] Centers for Disease Control and Prevention, “2003-2008 HIV Prevention Community Planning Guidance,” National Center for HIV, STD and TB Prevention, Atlanta, 2003. http://www.cdc.gov/hiv/pubs/hiv-cp.html

[59] R. Kennedy, "HIV on the Homefront," Metro Pulse, Vol. 18, No. 45, 2008, pp. 20-26.

[60] B. Mehra and K. S. Albright, "Health Information Services Available for People Living with HIV/AIDS: Perspectives of Library and Information Professionals," Proceedings of the $69^{\text {th }}$ Annual Meeting of the American Society for Information Science \& Technology 2006: Information Realities: Shaping the Digital Future For All, Vol. 43, Austin, 3-8 November 2006.

[61] B. G. Glaser and A. L. Strauss, "The Discovery of Grounded Theory: Strategies for Qualitative Research,” Aldine, Chicago, 1967.

[62] A. Strauss and J. Corbin, "Grounded Theory Methodology,” In: N. Denzin and Y. Lincoln, Eds., The Handbook of Qualitative Research, Sage Publications, Thousand Oaks, 1994, pp. 273-285. 